\title{
CHOSEN QUALITY PARAMETERS OF PORK SAUSAGE PRODUCED WITHOUT CURING MIXTURE
}

\author{
Adam Kostecki ${ }^{1}$, Agnieszka Bilska², Bożena Danyluk ${ }^{2 \bowtie}$ \\ ${ }^{1}$ AMCO Company Ltd., Kasztanowa 88, Dybów Kolonia, 05-250 Radzymin, Poland \\ ${ }^{2}$ Institute of Meat Technology, Poznań University of Life Sciences \\ Wojska Polskiego 31, 61-624 Poznań, Poland
}

\begin{abstract}
Background. The aim of this study was to determine the influence of the dried celeriac juice addition, as a nitrogenous compounds sources, on the quality of the experimental pork sausage.

Material and methods. In the sausages with vegetable preparation addition and in traditionally cured sausages amount of the sodium nitrate (III) and sodium nitrate (V) was determined (in the batter and $24 \mathrm{~h}$ after production). Moreover the total number of aerobic bacteria, number of coli forms, anaerobic survived bacteria, coagulase positive staphylococci, Listeria monocytogenes and occurrence of Salmonella in $25 \mathrm{~g}$ (according to Polish Standards) was determined during sausages storing (after 2, 14 and 21 days). Also sensory evaluation was carried out (after 2 and 14 days). After 2, 7, 14 and 21 days the amount of drip loss in the package was determined.

Result. In the experimental sausage produced with the addition of vegetable preparation (E0), the content was 2.2 times higher of sodium nitrate $(\mathrm{V})$ while sodium nitrate (III) three times lower, compared to traditionally cured sausages $(\mathrm{K})$. In the E0 sausages faster aerobic microorganisms proliferation was observed. However, in these products, in comparison to the control group $(\mathrm{K})$, no higher contamination with coliform bacteria, anaerobic sporulating bacteria, coagulase positive Staphylococci, Listeria monocytogenes or Salmonella was found. The sensory evaluation (colour in cross-section, flavour, taste, consistency) showed no statistically significant difference between the experimental sausages.

Conclusions. In the sausages produced with dried celeriac juice addition there was above twice more sodium nitrate (V) and threefold less sodium nitrate (III) in comparison to traditionally cured sausages and faster growth of aerobic bacteria was demonstrated. Sensory quality of 'cold' and 'hot' sausages without curing salt was worse, but the score number was never lower than 4,1 , so the sausages were accepted. In the vacuum packaged sausages produced with the addition of vegetable preparation higher, about $0.3-0.4$ percent score, drip loss was found.
\end{abstract}

Key words: sausage, sodium nitrate (V), sodium nitrate (III), vegetable preparation

\section{INTRODUCTION}

The most important purpose of the producers is to secure the quality and safety of produced food (Bilska and Kowalski, 2014; Tril et al., 2011). The use of sodium nitrate (V) and sodium nitrate (III) in animal source foods causes problems. Regardless of the benefits resulting from the application of sodium nitrate (III), the potential health risk caused by the use of this component has been indicated for a long time. As a result of the reaction

『danyluk@up.poznan.pl 
between sodium nitrate (III) and amide nitrogen or secondary, tertiary and quaternary amines contained in meat, nitrosamines may be formed, which are potentially carcinogenic substances to humans (Ciemniak, 2006; Gajowiecki et al., 2005). Sodium nitrate (III) are toxic compounds and they may be harmful to human health. Therefore, products made with nitrites do not meet contemporary consumers' requirements (Adamczak et al., 2010; Honikiel, 2008; Pietrasik et al., 2003).

Sodium nitrate (III) gives meat products a characteristic, desirable pink and red colour and palatability. It generates a typical curing aroma and has an antioxidative and bacteriostatic effect (Gajowiecki et al., 2005; Honikiel, 2008; Horsch et al., 2014; Sebranek and Bacus, 2007).

In the perception of consumers, sources of sodium nitrate (III) in food include first of all meat products (Sebranek and Bacus, 2007). Information on sodium nitrate (V) content in vegetables is less publicised, although it is known that they may include higher amounts of these compounds than animal origin food. It is assumed that vegetables and their processed products supply over $80 \%$ sodium nitrate (V) and sodium nitrate (III) found in daily food ration, while cured meat, cheeses and smoked meat products $-16 \%$ (Tietze et al., 2007). A particularly high content of sodium nitrate $(\mathrm{V})$ was found in fresh vegetables: radish, beets, cabbage, carrot and celeriac (Łozowicka, 2009; Sebranek and Bacus, 2007; Tietze et al., 2007). Thus producers of meat products focus on these processed products, in which vegetables are sources of sodium nitrate $(\mathrm{V})$. The addition of denitrifying bacteria causes sodium nitrate $(\mathrm{V})$ to be transformed into sodium nitrate (III). This method enables an adequate reaction of haem pigments in meat (Adamczak et al., 2010; Horsch et al., 2014; Lücke, 2008; Sebranek and Bacus, 2007 Sebranek et al., 2012).

The aim of this study was to determine the effect of added vegetable preparation containing dried celeriac juice as a source of sodium nitrate (V) on the quality of pork, scalded, semi coarse ground sausage, during cold storage.

\section{MATERIAL AND METHODS}

Material for analyses comprised experimentally produced semi coarse ground sausages (denoted as $\mathrm{K}$ and $\mathrm{E} 0$ ), produced from pork meat grades IIA, IIB and III.
Sausage denoted as $\mathrm{K}$ was produced with an addition of a curing blend $\left(99.6 \%\right.$ salt $\left.+0.4 \% \mathrm{NaNO}_{3}\right)$, sodium ascorbate (E301) and monosodium glutamate (E621).

Sausage denoted as E0 was supplemented with a vegetable preparation and starter cultures - denitrifying bacteria. In contrast, sodium ascorbate and monosodium glutamate were not applied, as substances denoted as E. The raw material composition of experimental sausages is given in Table 1 .

Meat grades IIA and IIB was comminuted in a grinder using plate for grinder with $8 \mathrm{~mm}$ diameter of orifices and meat grade III with $3 \mathrm{~mm}$ diameter of orifices. In the case of the control sample (K) after the addition of curing salts batter was mixed for $3 \mathrm{~min}$, then preparation Z50 was added and the entire volume was mixed for another $10 \mathrm{~min}$. In turn, batter for the production of the sample without the curing blend (E0) was supplemented with salt, after 3 min mixing the vegetable preparation was added and the whole volume was mixed for another $10 \mathrm{~min}$. Next with the use

Table 1. Raw material composition of experimental sausages, $\mathrm{kg}$

\begin{tabular}{|c|c|c|}
\hline \multirow{2}{*}{ Raw material and additives } & \multicolumn{2}{|c|}{ Sausage variant } \\
\hline & K & E0 \\
\hline Pork meat grade IIA & 65.5 & 65.0 \\
\hline Pork meat grade IIB & 25.0 & 25.0 \\
\hline Pork meat grade III & 10.0 & 10.0 \\
\hline Water & 19.3 & 19.3 \\
\hline Curing blend $\left(99.6 \% \mathrm{NaCl}+0.4 \% \mathrm{NaNO}_{2}\right)$ & 2.2 & - \\
\hline Sodium ascorbate & 0.03 & - \\
\hline Monosodium L-glutamate & 0.05 & - \\
\hline $\mathrm{NaCl}$ & - & 2.2 \\
\hline Spices & 1.0 & 1.0 \\
\hline $\begin{array}{l}\text { Preparation ion Z50 (dextrose, sucrose, } \\
\text { cane sugar, pork protein, maltodextrin) }\end{array}$ & 2.5 & - \\
\hline $\begin{array}{l}\text { Vegetable preparation (dextrose, sucrose, } \\
\text { cane sugar, pork protein, dried celeriac } \\
\text { juice) }\end{array}$ & - & 2.5 \\
\hline $\begin{array}{l}\text { Starter cultures (a mixture of Staphylococcus } \\
\text { carnosus and Staphylococcus vitulinus) }\end{array}$ & - & 0.01 \\
\hline
\end{tabular}


of a stuffing machine the batter was stuffed into swine intestines of $26-32 \mathrm{~mm}$ in diameter. After links were formed they settled for $2 \mathrm{~h}$ at $20^{\circ} \mathrm{C}$. Sausages produced with an addition of sodium nitrate (III) were next dried $\left(50^{\circ} \mathrm{C}, 20 \mathrm{~min}\right)$, smoked $\left(70^{\circ} \mathrm{C}, 45 \mathrm{~min}\right)$, scalded $\left(78^{\circ} \mathrm{C}\right.$, until the temperature of $72^{\circ} \mathrm{C}$ was reached inside the link) and cooled with cold water for $20 \mathrm{~min}$. Sausages produced with an addition of the vegetable preparation after settling were left at $40^{\circ} \mathrm{C}$ and $80 \%$ relative humidity of air for $60 \mathrm{~min}$ (the most advantageous conditions for the activation and proliferation of selected denitrifying bacteria - ageing process). Then the sausages (E0) were dried, smoked, scalded and cooled, analogously as in the control sausage.

Produced sausages after cooling to $8^{\circ} \mathrm{C}$, i.e. after $24 \mathrm{~h}$, were vacuum packaged and cold stored $\left(4-6^{\circ} \mathrm{C}\right)$.

The following analyses were performed during storage:

- Microbiological analyses at days 2, 14 and 21 from the completion of the production process (total count of aerobic bacteria according to the standard PN-EN ISO 4833-2004, count of coliform bacteria according to PN ISO 16649-2-2004, coagulase positive Staphylococci according to PN-EN ISO 6888-1:2001, L. monocytogenes - PN-EN ISO 11290$-2-2000$ and the presence of Salmonella in $25 \mathrm{~g}$ was analysed according to PN-EN ISO 6579-2003.

- Sensory examination on days 2 and 14 . Sensory examination was conducted by a panel of five individuals, who ascribed to each attribute a score depending on the quality grade: 5 - very good quality, 4 - good quality, 3 - satisfactory, 2 - unsatisfactory and 1 - bad. In each product the evaluated parameters included colour at cross-section, taste, aroma and consistency. Based on the results a value was obtained, constituting the overall score. The following weighting coefficients were applied: 0.3 - structure and consistency, 0.3 - colour at crosssection and 0.4 - taste and aroma. Sausages were evaluated when cold, i.e. 30 min after being taken out of the cooler $\left(4-6^{\circ} \mathrm{C}\right)$ - temperature in the room $24-25^{\circ} \mathrm{C}$; sausages were evaluated when they were cold, i.e. after the temperature inside the link was $14^{\circ} \mathrm{C}$, and when they were hot, i.e. after scalding.

- The volume of drip from the product to the packaging after 2, 7, 14 and 21 days. In order to determine the amount of drip from the product to the packaging, packaged samples of 2 sausage links were weighed. Next, after the packaging was opened, the packaging and dried sausage without drip were weighed. Based on the differences in the mass, i.e. contents (with drip and without it) the percentage share of drip was calculated.

In the samples $(\mathrm{K})$ and $(\mathrm{E} 0)$, in the batter, after ageing (E0), settling (K) and after $24 \mathrm{~h}$, contents of sodium nitrate (III) and sodium nitrate (V) were determined. The IC-HPLC method was applied (PN-EN 12014-4:2006P).

Recorded results were subjected to statistical analysis using Statistica 10.0 and Excel 2007. Two-way analysis of variance ANOVA was applied and to verify significant differences Tukey's multiple comparison test was used. The level of significance was $p \leq 0.05$.

\section{RESULTS AND DISCUSSION}

The contents of sodium nitrate (V) and sodium nitrate (III), determined in the experimental sausages are shown in Table 2. In batter $\mathrm{K}$ the amount of sodium nitrate (III) was $106.60 \mathrm{mg} / \mathrm{kg}$. A relatively slight amount of sodium nitrate $(\mathrm{V})(15.67 \mathrm{mg} / \mathrm{kg})$ was also detected. In the final product $24 \mathrm{~h}$ after the completion of production the content of sodium nitrate (III) was $91.30 \mathrm{mg} / \mathrm{kg}$, while that of sodium nitrate $(\mathrm{V})$ was $8.31 \mathrm{mg} / \mathrm{kg}$.

Experimental sausage E0 was not cured in the conventional process. Sodium nitrate (V) was introduced to the batter in the form of vegetable preparation. The preparation contained dextrose, sucrose, cane sugar, pork protein and dried celeriac juice. The vegetable preparation contained $1610 \mathrm{mg} / \mathrm{kg}$ nitrates.

In batter $\mathrm{E} 0$ the content of sodium nitrate $(\mathrm{V})$ was $58.37 \mathrm{mg} / \mathrm{kg}$ (total amount from vegetable preparation and meat), while no sodium nitrate (III) was detected. In the technological process of experimental sausage E0 batter was subjected to ageing. During that phase under the influence of added denitrifying bacteria some sodium nitrate $(\mathrm{V})$ were reduced to sodium nitrate (III) and after heating the batter contained both sodium nitrate (V) $(20.80 \mathrm{mg} / \mathrm{kg})$ and sodium nitrate (III) $(31.20 \mathrm{mg} / \mathrm{kg})$. Similarly as in the case of the control, in the final product E0 the amount of these compounds decreased and at $24 \mathrm{~h}$ after production it was $18.60 \mathrm{mg} / \mathrm{kg} \mathrm{NaNO}$ and $30.60 \mathrm{mg} / \mathrm{kg} \mathrm{NaNO}$. In comparison to the control sample $(\mathrm{K})$ the content of 
Kostecki, A., Bilska, A., Danyluk, B. (2015). Chosen quality parameters of pork sausage produced without curing mixture. Acta Sci. Pol. Technol. Aliment., 14(3), 191-198. DOI: 10.17306/J.AFS.2015.3.20

Table 2. Mean contents of nitrites and nitrates in experimental sausages $(N=5), \mathrm{mg} / \mathrm{kg}$

\begin{tabular}{lccccc}
\hline \multirow{2}{*}{$\begin{array}{c}\text { Sample } \\
\text { type }\end{array}$} & $\begin{array}{c}\text { Nitrogen } \\
\text { compound }\end{array}$ & batter & ageing & $\begin{array}{c}\text { Phase of technological process } \\
\text { after settling }\end{array}$ & $\begin{array}{c}\text { sausage } 24 \mathrm{~h} \\
\text { post production }\end{array}$ \\
\cline { 3 - 6 } $\mathrm{K}$ & $\mathrm{NaNO}_{3}$ & $15.67 \pm 0.17$ & - & $12.50 \pm 0.15$ & $8.31 \pm 0.09$ \\
& $\mathrm{NaNO}_{2}$ & $106.60 \pm 0.45$ & - & $94.40 \pm 0.35$ & $91.30 \pm 0.28$ \\
\hline Total & & 122.27 & - & 106.90 & 99.61 \\
\hline E0 & $\mathrm{NaNO}_{3}$ & $58.37 \pm 0.27$ & $20.80 \pm 0.22$ & - & $18.60 \pm 0.19$ \\
& $\mathrm{NaNO}_{2}$ & - & $31.20 \pm 0.25$ & - & $30.60 \pm 0.21$ \\
\hline Total & & 58.37 & 52.00 & - & 49.20 \\
\hline
\end{tabular}

sodium nitrate $(\mathrm{V})$ in the tested sausage (E0) was 2.2 fold higher, while sodium nitrate (III) three times lower. An approximately 2 - fold reduction in the amount of sodium nitrate (III) and approx. two-fold increase in the content of sodium nitrate $(\mathrm{V})$ was also recorded by Adamczyk et al. (2010) in finely comminuted sausages produced with an addition of vegetable preparation SUPER HAM ${ }^{\circledR}$ KOE 2006 in comparison to traditionally cured sausages. The potential to reduce the amount of sodium nitrate (III) in meat products was also indicated by Lücke (2008).

Due to the lower content of sodium nitrate (III) in the sausages (E0) after 2,14 and 21 days of cold storage microbiological purity was determined and compared with control sausage. As it is indicated by the results presented in Table 3, growth dynamics of aerobic microorganisms was lower in the control. Except for 2 - day storage in each successive cold storage time (14 and 21 days) in samples containing vegetable preparation a greater number of aerobic bacteria was found than in the control and the differences were significant statistically. Conducted microbiological analyses did not show an effect of the curing mixture and celeriac preparation on changeability of contamination of samples with coliform bacteria, anaerobic sporulating bacteria, coagulase positive Staphylococci, Listeria monocytogenes and Salmonella. Also results of analyses conducted at the Institute of Food

Table 3. Results of microbiological analyses of experimental sausage $(N=5)$

\begin{tabular}{cccccccc}
\hline $\begin{array}{c}\text { Sample } \\
\text { type }\end{array}$ & $\begin{array}{c}\text { Storage } \\
\text { time } \\
\text { days }\end{array}$ & $\begin{array}{c}\text { Total count of } \\
\text { aerobic bacteria } \\
\text { log cfu/g } \\
\bar{x} \pm \mathrm{s}\end{array}$ & $\begin{array}{c}\text { Coliform } \\
\text { bacteria } \\
\text { cfu/g }\end{array}$ & $\begin{array}{c}\text { Anaerobic } \\
\text { sporulating } \\
\text { bacteria } \\
\text { cfu/g }\end{array}$ & $\begin{array}{c}\text { Coagulase } \\
\text { positive } \\
\text { Staphylococci } \\
\text { cfu/g }\end{array}$ & $\begin{array}{c}\text { L. monocytogenes } \\
\text { cfu/g }\end{array}$ & $\begin{array}{c}\text { Salmonella } \\
\text { in } 25 \mathrm{~g}\end{array}$ \\
\hline $\mathrm{K}$ & 2 & $2.24^{\mathrm{a}} \pm 0.22$ & $<10$ & $<10$ & $<10$ & $<10$ & $\mathrm{nb}$ \\
& 14 & $4.08^{\mathrm{b}} \pm 0.61$ & $<10$ & $<10$ & $<10$ & $<10$ & $\mathrm{nb}$ \\
$\mathrm{E} 0$ & 21 & $7.31^{\mathrm{d}} \pm 0.20$ & $<10$ & $<10$ & $<10$ & $<10$ & $\mathrm{nb}$ \\
& $2.34^{\mathrm{a}} \pm 0.21$ & $<10$ & $<10$ & $<10$ & $<10$ & $\mathrm{nb}$ \\
& 14 & $4.56^{\mathrm{c}} \pm 0.17$ & $<10$ & $<10$ & $<10$ & $<10$ & $\mathrm{nb}$ \\
& 21 & $8.28^{\mathrm{e}} \pm 0.19$ & $<10$ & $<10$ & $<10$ & $<10$ & $\mathrm{nb}$ \\
\hline
\end{tabular}

Legend: $\bar{x}$ - mean value, $N$ - number of replications, $\mathrm{s}-$ standard deviation, $\mathrm{nb}$ - not found, a, $\mathrm{b}, \mathrm{c}-$ mean values in columns denoted with different letters differ statistically significantly according to Tukey's test $(p \leq 0.05)$. 
Technology, the University of Hohenheim (Fischer et al., 2005) showed no deterioration of microbiological quality of scalded sausage produced using a blend of spices with defined nitrate contents. On the basis of those analyses affirmed that the count of bacteria from the family Enterobacteriaceae and the total count of aerobic microorganisms in sausages produced with no addition of curing salts did not differ from the count of these bacteria in traditionally cured sausages. Sodium nitrate (III) prevents food poisonings caused by $\mathrm{Clo}$ stridium botulinum, but doesn't inhibit Listeria monocytogenes or lactic acid bacteria from proliferation (Lücke, 2008). Results of presented studies indicate that the application of celeriac juice as a source of nitrates results in a more rapid proliferation of aerobic microorganisms. They are saprophytic microorganisms, which at high concentrations cause a deterioration of sensory attributes of the product. Certain potential to extend shelf life of meat products is provided by the introduction of lactates to the formulation. A study by Gajowiecki et al. (2005) showed that substitution of sodium nitrite with an addition of lactates in the production of poultry products provides microbiologically safe processed meats. Lactates, similarly as lactic acid, highly effectively inhibit growth of microorganisms causing food spoilage and pathogenic microorganisms, including Clostridium botulinum and Listeria monocytogenes (Bibngol et al., 2014; Juneja et al., 2014; Miller and Acuff, 1994). The bacteriostatic action of lactates consists not only in reducing water activity in the products, but also in the specific effect of lactate ions (Miller and Acuff, 1994; Stekelenburg, 2003). As a result of the reversal of dissociation of weak acid from the lactate ion an undissociated - and thus also more active form of lactic acid is formed.

Due to high microbiological contamination of the experimental sausages after 21 days of cold storage sensory examination was conducted only after 2 and 14 days of storage. Sensory examination was performed on cold and hot sausages, with the results given in Table 4 and 5.

During the assessment of 'cold' samples only in the colour in the cross-section and in consistency did not reveal statistically significant differences between the control samples and the samples with a vegetable preparation added (E0) at the next term of analyses. The assessment team also observed that there was a slight but statistically significant decrease in the desirable aroma in the sample with dried celery juice on the 14th day after production. On the other hand, the taste of E0 samples was assessed at a statistically significant lower level than the control samples both on the second and fourteenth day of cold storage. However, it is necessary to stress the fact that the samples never scored less than 4.1 points, which was a sign of their good quality. In the total sensory assessment affirmed that the control sample received higher statistically significant marks than the sample with the vegetable preparation (E0), regardless of the fact if it was the second or fourteenth day of the cold storage.

The assessment of 'hot' samples also did not reveal differences in colour in the cross-section or in consistency between the control samples and the samples with

Table 4. Results of sensory examination of experimental sausages evaluated when cold $(N=5 ; \bar{x} \pm \mathrm{s})$

\begin{tabular}{ccccccc}
\hline & & \multicolumn{5}{c}{ Attribute } \\
\cline { 3 - 6 } $\begin{array}{c}\text { Sample } \\
\text { type }\end{array}$ & $\begin{array}{c}\text { Nitrogen } \\
\text { compound }\end{array}$ & $\begin{array}{c}\text { colour at } \\
\text { cross-section } \\
\bar{x} \pm \mathrm{S}\end{array}$ & $\begin{array}{c}\text { taste } \\
\bar{x} \pm \mathrm{S}\end{array}$ & $\begin{array}{c}\text { aroma } \\
\bar{x} \pm \mathrm{s}\end{array}$ & $\begin{array}{c}\text { consistency } \\
\bar{x} \pm \mathrm{s}\end{array}$ & $\begin{array}{c}\text { overall score } \\
\bar{x} \pm \mathrm{s}\end{array}$ \\
\hline $\mathrm{K}$ & 2 & $4.5^{\mathrm{a}} \pm 0.0$ & $4.5^{\mathrm{b}} \pm 0.0$ & $4.5^{\mathrm{b}} \pm 0.0$ & $4.5^{\mathrm{b}} \pm 0.0$ & $4.5^{\mathrm{c}} \pm 0.0$ \\
$\mathrm{E} 0$ & 14 & $4.5^{\mathrm{a}} \pm 0.0$ & $4.5^{\mathrm{b}} \pm 0.0$ & $4.4^{\mathrm{ab}} \pm 0.1$ & $4.5^{\mathrm{b}} \pm 0.0$ & $4.5^{\mathrm{bc}} \pm 0.0$ \\
& 2 & $4.6^{\mathrm{a}} \pm 0.1$ & $4.2^{\mathrm{a}} \pm 0.2$ & $4.5^{\mathrm{b}} \pm 0.0$ & $4.4^{\mathrm{a}} \pm 0.1$ & $4.4^{\mathrm{ab}} \pm 0.0$ \\
\hline
\end{tabular}

Legend: $\bar{x}$ - mean value, $N$ - number of replications, $\mathrm{s}$ - standard deviation, a, b, c-mean values in columns denoted with different letters differ statistically significantly according to Tukey's test $(p \leq 0.05)$. 
Kostecki, A., Bilska, A., Danyluk, B. (2015). Chosen quality parameters of pork sausage produced without curing mixture. Acta Sci. Pol. Technol. Aliment., 14(3), 191-198. DOI: 10.17306/J.AFS.2015.3.20

Table 5. Results of sensory examination of experimental sausages evaluated when hot $(N=5 ; \bar{x} \pm \mathrm{s})$

\begin{tabular}{|c|c|c|c|c|c|c|c|}
\hline \multirow[b]{2}{*}{$\begin{array}{l}\text { Sample } \\
\text { type }\end{array}$} & \multirow[b]{2}{*}{$\begin{array}{l}\text { Storage } \\
\text { time } \\
\text { days }\end{array}$} & \multicolumn{6}{|c|}{ attribute } \\
\hline & & $\begin{array}{c}\text { colour at } \\
\text { cross-section } \\
\bar{x} \pm \mathrm{S}\end{array}$ & $\begin{array}{l}\text { taste } \\
\bar{x} \pm \mathrm{s}\end{array}$ & $\begin{array}{c}\text { aroma } \\
\bar{x} \pm \mathrm{s}\end{array}$ & $\begin{array}{c}\text { consistency } \\
\bar{x} \pm \mathrm{S}\end{array}$ & $\begin{array}{c}\text { overall score } \\
\bar{x} \pm \mathrm{S}\end{array}$ & $\begin{array}{c}\text { colour at } \\
\text { cross-section } \\
\bar{x} \pm \mathrm{S}\end{array}$ \\
\hline \multirow[t]{2}{*}{ K } & 2 & $4.5^{a} \pm 0.0$ & $4.5^{\mathrm{b}} \pm 0.0$ & $4.5^{b} \pm 0.0$ & $4.5^{\mathrm{a}} \pm 0.0$ & $4.5^{\mathrm{b}} \pm 0.0$ & $4.5^{\mathrm{c}} \pm 0.0$ \\
\hline & 14 & $4.5^{\mathrm{a}} \pm 0.0$ & $4.5^{b} \pm 0.0$ & $4.4^{\mathrm{b}} \pm 0.1$ & $4.5^{\mathrm{a}} \pm 0.0$ & $4.5^{\mathrm{b}} \pm 0.0$ & $4.5^{\mathrm{c}} \pm 0.0$ \\
\hline \multirow[t]{2}{*}{ E0 } & 2 & $4.5^{\mathrm{a}} \pm 0.0$ & $4.1^{\mathrm{a}} \pm 0.2$ & $4.5^{\mathrm{b}} \pm 0.0$ & $4.4^{\mathrm{a}} \pm 0.1$ & $4.4^{\mathrm{a}} \pm 0.1$ & $4.3^{b} \pm 0.1$ \\
\hline & 14 & $4.5^{\mathrm{a}} \pm 0.0$ & $4.1^{\mathrm{a}} \pm 0.1$ & $4.1^{\mathrm{a}} \pm 0.2$ & $4.4^{\mathrm{a}} \pm 0.1$ & $4.4^{\mathrm{ab}} \pm 0.1$ & $4.3^{\mathrm{ab}} \pm 0.1$ \\
\hline
\end{tabular}

Legend as for Table 3.

the vegetable preparation on the second and fourteenth day after production. However, there were differences between the samples in the aroma and the structure. The difference in the structure was observed as early as the second day after production. On the other hand, a statistically significant difference in the aroma was observed only on the fourteenth day of cold storage. Both on the second and fourteenth day of storage the taste of E0 sample was ranked significantly lower than the control sample $(\mathrm{K})$. It resulted in a significantly worse score of the sample with celery juice. Similarly to the assessment of 'cold' samples, the examined sausages did not score less than 4.1 points.

Under the study the amount of leak in the package during the cold storage was determined. As was observed, the addition of dried celery juice caused a statistically significant increase in the amount of leak in the vacuum package after 7,14 and 21 days of cold storage, as compared with the traditionally cured samples (Table 6). On the other hand, there was a minimal

Table 6. Amount of drip in packaging during storage of experimental sausages $(\bar{x} \pm \mathrm{s}), \%$

\begin{tabular}{lcccc}
\hline \multirow{2}{*}{$\begin{array}{c}\text { Sample } \\
\text { type }\end{array}$} & \multicolumn{4}{c}{ Storage time, days } \\
\cline { 2 - 5 } & 2 & 7 & 14 & 21 \\
\hline $\mathrm{K}$ & $0.0^{\mathrm{a}} \pm 0.0$ & $0.1^{\mathrm{a}} \pm 0.1$ & $0.2^{\mathrm{ab}} \pm 0.1$ & $0.3^{\mathrm{bc}} \pm 0.1$ \\
E0 & $0.0^{\mathrm{a}} \pm 0.0$ & $0.4^{\mathrm{c}} \pm 0.1$ & $0.5^{\mathrm{cd}} \pm 0.1$ & $0.7^{\mathrm{d}} \pm 0.2$ \\
\hline
\end{tabular}

Legend: $\bar{x}$ - mean value, $\mathrm{s}-$ standard deviation, $\mathrm{a}, \mathrm{b}, \mathrm{c}-$ mean values in rows and columns denoted with different letters differ statistically significantly according to Tukey's test $(p \leq 0.05)$. but statistically significant increase in the leak observed in the control cold cut $(\mathrm{K})$ only 14 and 21 days after the end of the production process.

\section{CONCLUDING REMARKS}

In the experimental sausage (E0), i.e. produced with an addition of vegetable preparation containing dried celeriac juice an over two-fold greater amount of nitrate and three-fold lower amount of nitrites were found in comparison to the traditionally cured sausage. In these products aerobic microorganisms were developing more rapidly. In contrast, no greater contamination was found for coliform bacteria, anaerobic sporulating bacteria, coagulase positive Staphylococci, Listeria monocytogenes or Salmonella. In sensory examination both on cold and hot sausages the samples of sausages produced with no curing salts were characterised by inferior quality, although the scores were min. 4.1, which indicates their acceptance by the panel members. Application of celeriac juice in the production of sausage resulted in an increase in the amount of drip in vacuum packaging by $0.3-0.4$ percentage points.

\section{REFERENCES}

Adamczak, L., Florowski, T., Dąbkowska, A. (2010). Porównanie jakości kiełbas drobno rozdrobnionych peklowanych tradycyjnie i z wykorzystaniem preparatu warzywnego jako źródła azotanów V [Comparison of the quality of frankfurter type sausages cured by traditional method or with addition of vegetable extract as a source of nitrates]. Nauka Przyr. Technol., 4, 5, 1-7 [in Polish]. 
Bilska, A., Kowalski, R. (2014). Food quality and safety management. LogForum, 10(3), 353-361.

Bingol, E. B., Colak, H., Cetin, O., Hampikyan, H. (2014). Effects of sodium lactate on the shelf life and sensory characteristics of cig kofte - A Turkish traditional raw meatball. J. Food Process. Pres., 38, 3, 1024-1036.

Ciemniak, A. (2006). Porównanie zawartości N-nitrozodimetyloaminy w wybranych produktach mięsnych [A comparison of n-nitrosodimethylamine contents in selected meat products]. Rocz. PZH, 57, 4, 341-346 [in Polish].

Fischer, A., Bristle, A., Gehring, U., Herrmann, K., Gibis, M. (2005). Umrötung von Brühwurst ohne Nitrit Pökelsalz. Fleischwirtschaft, 85(4), 110-115; 85(5), 106-109.

Gajowiecki, L., Kotowicz, M., Lachowicz, K., Dąbrowski, W., Koronkiewicz, A., Żochowska-Kujawska, A., Sobczak, M., Żych, A. (2005). Zastosowanie mleczanów do produkcji wyrobów drobiowych niezawierających dodatku azotanu (III) sodu [Use of lactates in processing of poultry meat products without sodium nitrate (III) addition]. Żywn. Nauka Techn. Jakość, 3(48), 86-99 [in Polish].

Honikel, K. O. (2008). The use and control of nitrate and nitrite for the processing of meat products. Meat Sci., 78(1-2), 68-76.

Horsch, A. M., Sebranek, J. G., Dicksonb, J. S., Niebuhr, S. E., Larson, E. M., Lavieri, N. A., ..., Wilson, L. A. (2014). The effect of $\mathrm{pH}$ and nitrite concentration on the antimicrobial impact of celery juice concentrate compared with conventional sodium nitrite on Listeria monocytogenes. Meat Sci., 96, 400-407.

Juneja, V., Mukhopadhyay, S., Marks, H., Mohr, T. B., Warning, A., Datta A. (2014). Predictive thermal inactivation model for effects and interactions of temperature, $\mathrm{NaCl}$, sodium pyrophosphate, and sodium lactate on listeria monocytogenes in ground beef. Food Bioproc. Tech., 7, 2, 437-446.

Lücke, F.-K. (2008). Nitrit und die Haltbarkeit und Sicherheit erhitzter Fleischprodukte [Effect of the use of nitrite on safety and shelf life of cooked meats]. Fleischwirstschaft, 88(12), 91-94.

Łozowicka, B. (2009). Zanieczyszczenia chemiczne w żywności pochodzenia roślinnego [Chemical contamination in food of plant]. Post. Ochr. Rośl., 49(4), 2071-2080 [in Polish].

Miller, R. K., Acuff, G. R. (1994). Sodium lactate affects pathogens in cooked beef. J. Food Sci., 59, 15-19.

Pietrasik, Z., Duda, Z., Jarmoluk, A. (2003). Wpływ zmiennego poziomu wybranych preparatów barwotwórczych na wyróżniki barwy modelowych kiełbas o obniżonym dodatku azotynu sodu [Effect of varying levels of selected colourants on colour attributes of sausages manufactured with reduced sodium nitrite additive]. Acta Sci. Pol. Technol. Aliment., 2(1), 143-153 [in Polish].

PN ISO 16649-2-2004. Mikrobiologia żywności i pasz. Horyzontalna metoda oznaczania liczby ß-glukuronidazo-dodatnich Escherichia coli [Microbiology of food and feed. Horizontal method for the enumeration of ß-glucuronidase-positive Escherichia coli] [in Polish].

PN-EN ISO 11290-2-2000. Mikrobiologia żywności i pasz. Horyzontalna metoda wykrywania obecności i oznaczania liczby Listeria monocytogenes [Microbiology of food and feed. Horizontal method for detection and enumeration of Listeria monocytogenes] [in Polish].

PN-EN ISO 4833-2004. Mikrobiologia żywności i pasz. Horyzontalna metoda oznaczania liczby drobnoustrojów [Microbiology of food and feed. Horizontal method for the enumeration of microorganisms] [in Polish].

PN-EN 12014-4:2006P. Artykuły żywnościowe. Oznaczanie zawartości azotanów i/lub azotynów. Część 4: Oznaczania zawartości azotanów i azotynów w produktach mięsnych metodą chromatografii jonowymiennej (IC) [Foodstuffs. Determination of nitrates and/or nitrites. Part 4. Determination of nitrates and nitrites in meat products by ion exchange chromatography (IC)] [in Polish].

PN-EN ISO 6579-2003. Mikrobiologia żywności i pasz. Horyzontalna metoda wykrywania Salmonella spp. [Microbiology of food and feed. Horizontal method for the detection of Salmonella spp.] [in Polish].

PN-EN ISO 6888-1:2001. Mikrobiologia żywności i pasz. Horyzontalna metoda oznaczania liczby gronkowców koagulazo-dodatnich (Staphylococcus aureus i innych gatunków) Część 1: Metoda z zastosowaniem pożywki agarowej Baird-Parkera [Microbiology of food and feed Horizontal method for the enumeration of coagulase-positive staphylococci (Staphylococcus aureus and other species) Part 1: Method using Baird-Parker agar] [in Polish].

Sebranek, J. G., Bacus, J. N. (2007). Cured meat products without direct addition of nitrate or nitrite: what are the issues? Meat Sci., 77, 136-147.

Sebranek, J. G., Jackson-Davis, A. L., Myers, K. L., Lavieri, N. A. (2012). Beyond celery and starter culture: advances in natural/organic curing processes in the United States. Meat Sci., 92, 267-273.

Stekelenburg, F. K. (2003). Enhanced inhibition of Listeria monocytogenes in frankfurter sausage by the addition of potassium lactate and sodium diacetate mixtures. Food Microbiol., 20, 133-137. 
Tietze, M., Burghardt, A., Brągiel, P., Mac, J. (2007). Zawartość związków azotowych w produktach spożywczych [Content of nitrosamines in foodstuff]. Ann. Univ. Mariae Curie-Sklodowska, 35(1), 71-77 [in Polish].

Tril, U., Salejda, A. M., Krasnowska, G. (2011). Próba zwiększenia stabilności oksydacyjnej modelowych przetworów mięsnych poprzez zastosowanie soku z aronii [Attempt to increase oxidative stability of model meat products by applying chokeberry juice]. Żywn. Nauka Techn. Jakość, 6(79), 55-66 [in Polish].

\section{CHARAKTERYSTYKA JAKOŚCI KIEtBAS WIEPRZOWYCH WYTWARZANYCH BEZ DODATKU MIESZANKI PEKLUJĄCEJ}

\section{STRESZCZENIE}

Wstęp. Celem pracy było określenie wpływu dodatku suszonego soku z selera, jako źródła azotanów, na jakość eksperymentalnej kiełbasy wieprzowej oraz jej zmiany w czasie przechowywania poprodukcyjnego. Materiat i metody. W kiełbasach z dodatkiem preparatu warzywnego i peklowanych tradycyjnie oznaczono zawartość azotanów (III) i (V) (w farszu i po 24 h). Ponadto w czasie przechowywania (po 2, 14 i 21 dobie) określono w kiełbasach ogólną liczbę bakterii tlenowych, liczbę bakterii z grupy coli, beztlenowych bakterii przetrwalnikujących, gronkowców koagulazododatnich, bakterii Listeria monocytogenes oraz obecność Salmonella w 25 g (zgodnie z Polską Normą). Wykonano również ocenę sensoryczną (po 2 i 14 dobie). Po 2, 7, 14 i 21 dobach oznaczono ilość wycieku w opakowaniach.

Wyniki. W kiełbasach doświadczalnych, wyprodukowanych z dodatkiem preparatu warzywnego (E0), zawartość azotanów (V) była 2,2 raza większa, natomiast zawartość azotanów (III) była trzykrotnie mniejsza w porównaniu z kiełbasami peklowanymi tradycyjnie $(\mathrm{K})$. W wędlinach E0 szybciej namnażały się drobnoustroje tlenowe. W wyrobach tych nie stwierdzono jednak, w porównaniu z grupą kontrolną (K), większego zanieczyszczenia bakteriami z grupy coli, beztlenowymi bakteriami przetrwalnikującymi, gronkowcami koagulazododatnimi, bakteriami Listeria monocytogenes oraz Salmonella. W ocenie sensorycznej (barwa na przekroju, zapach, smak, konsystencja) nie stwierdzono statystycznie istotnych różnic pomiędzy badanymi próbkami kiełbas wytwarzanych eksperymentalnie.

Wnioski. W kiełbasach sporządzanych z dodatkiem suszonego soku z selera stwierdzono ponad dwukrotnie większą ilość azotanów i trzykrotnie mniejszą azotynów w porównaniu z kiełbasami peklowanymi tradycyjnie oraz wykazano szybsze namnażanie się drobnoustrojów tlenowych. W ocenie sensorycznej kiełbas zimnych i po ogrzaniu, próbki sporządzone bez peklosoli charakteryzowały się gorszą jakością. Oceny jednak nigdy nie były niższe niż 4,1, co świadczy o ich akceptacji przez oceniających. W opakowaniach próżniowych wędlin produkowanych $\mathrm{z}$ dodatkiem preparatu warzywnego stwierdzano większe o $0,3-0,4$ punktu procentowego ilości wycieków.

Słowa kluczowe: kiełbasa, azotan (III), azotan (V), preparat warzywny

For citation - Do cytowania

Kostecki, A., Bilska, A., Danyluk, B. (2015). Chosen quality parameters of pork sausage produced without curing mixture. Acta Sci. Pol. Technol. Aliment., 14(3), 191-198. DOI: 10.17306/J.AFS.2015.3.20 